\title{
THE RELATIONSHIP BETWEEN PERSON-ORGANIZATION FIT, ORGANIZATIONAL IDENTIFICATION AND WORK OUTCOMES
}

\author{
Mahmut DEMIR ${ }^{1}$, Sirvan Sen DEMIR ${ }^{2}$, Kevin NIELD ${ }^{3}$ \\ ${ }^{1,2}$ Egirdir School of Tourism \& Hotel Management, \\ Suleyman Demirel University, Isparta, Turkey. \\ ${ }^{3}$ Sheffield Hallam University, Sheffield, UK \\ E-mails: ${ }^{1}$ mdemir1@gmail.com(corresponding author); \\ 2sirvansendemir@gmail.com; ${ }^{3}$ k.nield@shu.ac.uk
}

Received 18 January 2013; accepted 12 March 2013

\begin{abstract}
The purpose of this research is to analyse the relationship of person-organization fit in hotels through organizational identification, job performance, production deviance behavior, and the intention to remain. To achieve this, first the literature was consulted to provide a conceptual model. Through conducting a face-to-face interview, a total of 582 questionnaires were collected from employees who were full-time employees of the five-star hotels operating within the Mugla region of Turkey. The data obtained from the survey was analysed via the statistics program; within this explanatory and confirmatory factor analyses were performed within the framework of Structural Equation Modelling. The study concluded and identified, that external factors, namely "personorganization fit", have an effect on internal factors such as "organizational identification", "job performance", "production deviance" and the "intention to remain". The empirical results indicate that person-organization fit has a significant and positive influence on organizational identification, job performance and intention to remain, while has a significant and negative influence on production deviance behavior. The results also indicate that the organizational identification has an important effect on job performance, intention to remain and production deviance behavior.
\end{abstract}

Keywords: person-organization fit, organizational identification, job performance, production deviance behavior, intention to remain, work outcomes.

JEL Classification: M12, M51, M54.

\section{Introduction}

Many researchers focus on the notion that in working life, the congruence an individual builds with the job that individual performs, and the organization they work for is substantially influential on work outcomes. Findings obtained from research on organizational behavior indicate that the personal traits of an employee, and the organizational characteristics are positively effective on outcomes such as ensuring organizational commitment (Da Silva et al. 2010), increasing employee performance (Kristof-Brown 
et al. 2005), providing job satisfaction (Liu et al. 2010), organizational citizenship behavior (Vogel, Feldman 2009), diminishing work stress (Fox et al. 2001; Sekuguchi 2004), decreasing the intention to leave (Demir 2010) or strengthening the intention to remain (Da Silva et al. 2010), alleviating organizational deviance behavior (Demir 2011). Person-organisation (P-O) fit is not only related to work outcomes or organizational success; it is also beneficial due to the positive atmosphere it may create through reciprocal interaction in terms of work environments, social environments, and the vocation leading to an increased organizational commitment from employees.

The organizational identification (O-Id) concept, which has been analysed in the current research in respect to its mediator role between external factors and work outcomes, in fact creates a psychological effect in reflecting the relationship between the individual and organization. Reaching beyond the organizational commitment of employees, this concept, which also includes organizational integration with vision, mission and its members, is interrelated to job satisfaction, motivation, personal and organizational success, perceived justice, career planning, organizational citizenship behavior and organizational trust (Demir 2011; Shamir, Kark 2004). The findings obtained from the literature review show that O-Id has both a direct and partial influential role in employee behaviors (Dutton et al. 1994; Miller et al. 2000). O-Id plays a positive role in elevating employees' intention to remain in, and be committed to the organization and organizational commitment, as well as creating a trust which will inevitably influence negative employee attitudes (Da Silva et al. 2010; Sekuguchi 2004). The significance of this bond becomes even more salient when it is identified that acting in unison within an organization and making decisions corresponding to organizational objectives, the identification of employees with the organization is greatly effective.

\section{Literature review}

\subsection{Person-organization fit (P-O fit)}

The integration of an organization with employees' demands and expectations, cultural structure and performance of individuals may be positively effective in organizational behavior. Person-job fit is defined as the congruence between an individuals' interests and abilities and the characteristics and requirements of their vocation (Carless 2005; Christensen, Wright 2011; Edwards 1991), and is considered to be among the major determinants of work outcomes and the components of working life, which has the power to directly affect organizational success (Nikolaou 2003). It is reasonable to assert that employees whose special abilities, background knowledge and cognitive skills, beliefs and values are in accord with the characteristics of their job can, compared to others, attain greater job satisfaction (Vogel, Feldman 2009). It is expected that P-O fit, particularly the physical and mental state and abilities of employees, must be sufficient to meet the job requirements, since in the employee selection process, the match between personal characteristics and job requirements is thought to be the primary factor in ensuring a person-vocation fit (Demir 2010). Selecting the best candidate to meet the job specifications is not only vital in composing effective and productive work teams, but 
also in preventing potential losses and damages during production and service presentation, and increasing financial profitability (Demir 2010; Sekuguchi 2004).

Described as the congruence between personal and organizational value sets (Chatman 1991; Sekuguchi 2004), P-O fit is analysed within an interactive relationship or a valuebased approach in respect to the theoretical organizational culture aspect. It matters greatly in terms of work outcomes that there is congruence between personal attitudes and behaviors formed through individuals' decisions, beliefs and organizational values (Chatman 1991; O'Reilly et al. 1991). The compatibility between personal values and priorities, and organizational values and priorities, is the key to a happier and safer work life, and an indicator of the desire to remain within the same organization (Ambrose et al. 2008; Song, Chathoth 2011). In that case, the person, whose internalized organizational values perform in a manner that prioritizes organizational gains, while working in harmony with the organization strengthens his/her position, offers advantages in domestic competition, and may be effective in the formation of organizational commitment. Supporting a similar approach, O’Reilly et al. (1991) argue that P-O fit is among one of the significant determinants of variables such as value (normative) commitment, job satisfaction, and intention to remain.

\subsection{Organizational identification (O-Id)}

O-Id, which is generally defined as the subjective description level of employees with organizational characteristics (Dutton et al. 1994) and, a unique form of social identity (Mael, Ashforth 1992) can change in respect to different individuals. Where beliefs and values of individuals fail to fit with organizational norms and regulations, an O-Id is likely to arise. It has been shown that O-Id factors in working life acts as a mediator between employee characteristics and organizational outcomes in terms of attitudes and behaviors (Dutton et al. 1994). The O-Id concept bears great potential in forming the attitudes and behaviors of an individual as a psychological component within the employee-organization relationship (Edward 2005).

When including the cooperation and common action between employees and an organization, the common values shared by all its members through the support of organizational behavior and mutual interaction (Miller et al. 2000; Sluss et al. 2008) assumes, that individuals with O-Id may be more inclined to work longer in order to support work outcomes. As the O-Id level of individuals' increases, they prioritize their organizational interests and act accordingly, which in turn enables an increase in their organizational thinking levels (Dutton et al. 1994). In some studies (Miller et al. 2000; Shamir, Kark 2004), O-Id is thought of as the image of a person's social identity, which is an output of organizational identity. Organizationally identified people view themselves in their social life as the agents of an organization, and are more likely to protect organizational interests.

\subsection{Job performance (J-Perf)}

In terms of employees, the concept of J-Perf is defined as the qualitative and quantitative achievement level of a job, and the evaluation of all related efforts and the resulting 
ratio of realizing the set target or mission (Johari, Yahya 2009; Vogel, Feldman 2009). As J-Perf is a basic phenomenon in attaining organizational and personal goals, it matters equally to organizations as well as employees. High performance indicators of an employee as a source of personal pride and honour, motivate that person more at work, and in the end may be effective in increasing job satisfaction, obtaining a higher income, achieving a better career and gaining social dignity (Vogel, Feldman 2009). In order to build an organizational culture, and within that context to heighten J-Perf, it is necessary to set certain standards and plans because it is envisaged that the driving power behind the J-Perf of employees is organizational culture. There are also some research (Kristof-Brown et al. 2005) findings demonstrating that organization culture enhances the J-Perf of individuals, the service quality and work life quality, while at the same time diminishing labour turnover and costs.

One of the main indicators in measuring J-Perf is employees' discharging their tasks on time, and to the required quality, amount and cost. Further in J-Perf, P-O fit is highly effective in aiding high J-Perf (Janssen, Van Yperen 2004). The active role job-employee fit plays an important role in decreasing production deviance, and is also effective in taking J-Perf to a higher level. In J-Perf, the job descriptions matching the employee's characteristics and the fulfilment of their responsibilities are also crucial elements.

\subsection{Production deviance behavior (PDB)}

Hollinger and Clark (1982), who analysed deviation behavior within the framework of workplace regulations under two groups as property and production deviance in an organizational dimension, alleged that these two deviance behaviors are indicators of $\mathrm{P}-\mathrm{O}$ misfit. Property deviation (equipment, tools, material etc.) includes negative behaviors towards an organization's resources and entities and the organization itself, while production deviance contains employees' behaviors that violate organizational norms on the quality and quantity of the work to be performed, hence causing failure in the process and model related to the job (Demir 2011). PDBs include leaving earlier than scheduled work time, taking excessive and longer amounts of break, causing a decrease in work and performance by slowing down the production. The extravagance in the consumption of organizational resources is also examined under this context.

The PDB is also described as threatening conduct against the positive structure of the organization, its members, or both through violating the organizational norms and regulations (Bennett, Robinson 2003; Aquino et al. 2004). Lawrence and Robinson (2007) explained deviance behavior also as intentional behaviors employees perform to hinder routine operations in the organization. Likewise, Vardi and Wiener (1996) have reported that deviance behavior is stopping the activities conducted to reach organizational goals. It is acknowledged that the reason for this high level of deviance behavior largely stems from the failure of employees to build O-Id.

\subsection{Intention to remain (IntR)}

IntR, described as the choice of an employee to stay in their existing job or quit (Demir 2011), can affect positively in achieving both organizational and personal goals, and 
forming organizational behavior. IntR is determined according to an individual's workrelated attitudes, behaviors and outcomes (Olkkonen, Lipponen 2006). Person-job fit, in other words, the non-presence of a situation necessitating the leave of an employee, intention to continue being a member of the same organization are accepted to be the indicators of fulfilment of personal expectations and demands to a large extent (Demir 2011; Mowday et al. 1982).

IntR, as an indicator of responsibility awareness of employees, largely eliminates the occurrence of arriving late to work, leaving early, neglecting the tasks, habitual absenteeism-excused or arbitrary (Morrow et al. 1999; Van Dick et al. 2004). The intention of employees to remain is perceived as an indicator that they feel satisfied with their job, and that they possess self-identify with the organization (Demir 2010; Liu et al. 2010). In the same way, it is also considered a sign that job-employee fit has been achieved. Employees' IntR can affect both sides positively through both its social and financial contributions.

\section{Conceptual model and hypotheses}

Based on the data obtained from literature, nine hypotheses within three main groups have been established to form the conceptual model used in this study. By handling the data that might contribute to hypotheses from different perspectives, the direction of the relationship between the factors has been effective in significant level and model setting. In Figure 1, conceptual model of research, comprises one external factor, three internal factors and one mediator factor.

The studies exhibiting the effect of P-O fit on work outcomes indicate that $\mathrm{P}-\mathrm{O}$ fit is directly associated with J-Perf, job satisfaction, organizational citizenship behavior, organizational commitment, IntR, absenteeism, intention to leave (De Clercq et al. 2008; Kristof-Brown et al. 2005). Additionally it is witnessed that P-O fit bears the role of mediator among certain variables-e.g. for instance person-vocation fit and

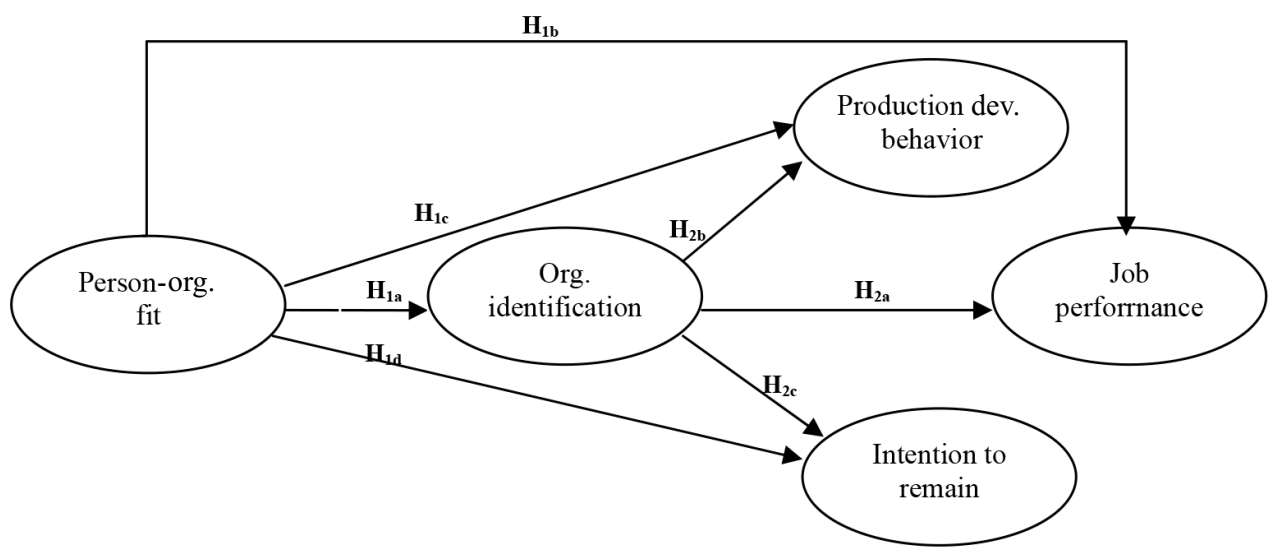

Fig. 1. Conceptual model 
work outcomes, creating self-respect and job satisfaction (Song, Chathoth 2011; Vogel, Feldman 2009).

On the other hand, as positive, strong and significant relationship between personvocation fit and job satisfaction (Kristof-Brown et al. 2005), it is concluded that in employee selection, consideration of person and job-supervisor-environment fit has a positive impact on work outcomes (Chatman 1991; Da Silva et al. 2010). Person-job fit enables an employee to build better relationships with the director and colleagues and reach higher J-Perf. It is agreed that in work life employees' characteristics play a vital role in the congruent interaction they can build with social environment (Ryan, Schmit 1996). It is furthermore suggested that while person-environment fit is positively related to personal career development, job satisfaction, organizational commitment and J-Perf but it is negatively related to resignations (Chatman 1991; Vogel, Feldman 2009). Some researchers who analyzed person-director fit based on leader-member interaction (e.g. Kristof-Brown et al. 2005) state that such congruence can, starting from the hiring process, affect work outcomes of individuals positively through the effective and productive performance of individuals. From this point onwards, it is feasible to list the hypotheses narrating the effect of P-O fit on work outcomes as below:

$\mathbf{H}_{1 \mathrm{a}}$ : P-O fit has a positive effect on organizational identification.

$\mathbf{H}_{1 \mathrm{~b}}$ : P-O fit has a positive effect on employees' job performance.

$\mathbf{H}_{1 \mathrm{c}}$ : P-O fit has a negative effect on employees' production deviance behavior.

$\mathbf{H}_{1 \mathrm{~d}}$ : P-O fit has a positive effect on employees' intention to remain.

In some research, the O-Id concept, is seen as the same as organizational commitment. In this research, O-Id is defined as possessing deeper attachment to the organization. Some researchers aiming to detect the effect of O-Id on J-Perf (Carmeli et al. 2007) have reported that the attitudes and behaviors an employee is engaged in work life can affect work outcomes positively. Aside from this other research also indicates, that O-Id is connected to job satisfaction, motivation, organizational commitment, organizational citizenship behavior, organizational communication, teamwork, and J-Perf (Shamir, Kark 2004).

Some studies (Olkkonen, Lipponen 2006; Wan-Huggins et al. 1998) related to O-Id has the positive and significant effect on IntR, show that organizational commitment has a crucial role on employees' behavioral intentions. In person-organization relations, where identification is high, there exists a more positive and motivating approach. In that case the perceiving work-related problems not only organizational but equally personal is the outcome of O-Id. Hence, in the formation of IntR there is at first common action and adoption in problem solving. In a study conducted by Van Dick et al. (2004) it has been detected that O-Id negatively and significantly affects employees' tendency to leave job. To put it differently, O-Id may be the hidden actor in strengthening the IntR. Nonetheless there are some studies (Van Knippenberg, Sleebos 2006) positing that there is no significant relationship between O-Id and IntR. Robinson and Bennett (1995) have defined organizational deviance behavior as the qualitative and quantitative damages done 
to production. Indeed certain relevant studies (Nair, Bhatnagar 2011; Olkkonen, Lipponen 2006) have also pointed to the negative effect of O-Id on employee deviation behavior and the significant relationship between both variables. Within the framework of these data, hypotheses on the effect of O-Id on work outcomes are stated as follows:

$\mathbf{H}_{2 \mathrm{a}}$ : O-Id has positive effect on job performance of employees.

$\mathbf{H}_{2 \mathrm{~b}}$ : O-Id has negative effect on production deviance behavior of employees.

$\mathbf{H}_{2 \mathrm{c}}$ : O-Id has positive effect on employees' intention to remain.

\section{Methodology}

\subsection{Sample and procedures}

The data used in this research was obtained via a survey that was prepared through face-to-face interviews conducted among employees, who had been working for a minimum one year in 5-star hotels belong to different chains within the Mugla region of Turkey, between May and October 2012. In this research a pre-test was conducted among 63 people. Finally, a total 841 surveys were distributed and 629 were completed and returned. 47 surveys were not assessed due to a lack of reliability; similarities in responses, all the answers are the same sleek etc. The number of evaluated surveys was 582 ; giving a return ratio of $69.2 \%$.

LISREL 8.80 program was used for the analysis. This analysis, constructed upon SEM, was conducted in two stages. In the first stage, reliability and structural validity analyses was performed. In the second stage, the procedures to measure the hypotheses were actualized. To that end, the first explanatory factor analysis was made in order to reveal average values, factor loads and standard values of factor groups within themselves. Finally, in order to analyse the factor groups' relationship to each other, and the structural validity of the model, confirmatory factor analysis was conducted.

\subsection{Measures and variables}

\subsubsection{P-O fit}

P-O fit scale was developed by employing Cable and DeRue (2002), Saks and Ashforth (2002)'s studies. The scale represented by a total of 5 variables was formed through a 5-point Likert type ( $5=$ strongly agree, $1=$ strongly disagree). In the scale there are questions related to the congruency of an individual, and his/her personal worth with the director, colleagues, the performed job and offered benefits. A pre-test was conducted to measure the structural validity of the P-O fit scale, and upon finding the acceptable ratio for social sciences it was then put into use. The reliability level of this scale (Cronbach Alpha) was determined as 0.91 .

\subsubsection{Organizational identification}

The variables related to the O-Id factor were adapted from the research of Van Dick et al. (2004), Mael and Ashforth (1992) in order to be appropriate for the current research. 
The O-Id scale prepared in a 5-point Likert type ( 5 = strongly agree, $1=$ strongly disagree) and consisted of 13 variables initially was reduced to 10 variables, as pre-test results indicated that 3 variables were a misfit with the factor structure. The reliability level of this scale (Cronbach Alpha) was determined as 0.88 .

\subsubsection{Job performance}

J-Perf assessment can be conducted by the superiors, subordinates, colleagues or employees themselves. In this approach, the employees' J-Perf is evaluated in respect to scores that reflect a certain ratio of quality and quantity (Katzell et al. 1992; Robbins 1998). In this research, previous studies were benefited (Nagy 2002; Williams, Anderson 1991) and based on the self-evaluation of the employees, a question set was formed. The J-Perf scale prepared in a 5-point Likert type ( $5=$ strongly agree, $1=$ strongly disagree) and consisting of 11 variables initially was reduced to 7 variables, as the pre-test results indicated that 4 variables were a misfit with factor structure. The reliability level of this scale (Cronbach Alpha) was determined as 0.86.

\subsubsection{Production deviance behavior}

Production deviance related variables adapted by Demir (2011) from Robinson and Bennett (1995) are listed under 4 titles as leaving early, taking excessive amounts of breaks, performance slowdown, and wasting organizational resources. The scale represented with a total of 4 variables was put together through 5-point Likert type ( 5 = strongly agree, $1=$ strongly disagree). The reliability level of this scale (Cronbach Alpha) was determined as 0.82 .

\subsubsection{Intention to remain}

The survey questions measuring the employees' IntR were modelled with the help of other previous research (Demir 2011; Lee, Way 2010; Van Dick et al. 2004). The scale represented by a total of 5 variables was formed through a 5-point Likert type ( 5 = strongly agree, $1=$ strongly disagree). The reliability level of this scale (Cronbach Alpha) was determined as 0.94 .

\section{Results}

In Table 1, the results of the correlation analysis demonstrate the inter-factor relationships. As the relationship of P-O fit with other factors is examined it is seen that P-O fit has significant, positive and a high degree of relationship to employees' $\operatorname{IntR}(\mathrm{r}=.67$; $\mathrm{p}<.01)$. Thus, it can reasonably be argued that in an employees' choice to remain or quit, the level of congruency with the organization may be among the major determinants. The person- organization fit has also a positive and significant relationship with O-Id $(\mathrm{r}=.42$; $\mathrm{p}<.01)$ and J-Perf $(\mathrm{r}=.51 ; \mathrm{p}<.01)$, but a significant, yet negative relationship with PDB $(\mathrm{r}=-.41 ; \mathrm{p}<.01)$. The fact that organizational fit contributes positively to a person's identification with the organization and J-Perf can also be regarded as positive outcomes. Achieving a person's fit with the organization may eradicate or alleviate PDBs. On the 
Table 1. Correlation analysis, mean and standard deviance

\begin{tabular}{lcccccccc}
\hline Factors & $\begin{array}{c}\text { No. of } \\
\text { variables }\end{array}$ & Mean & $\begin{array}{c}\text { Std. } \\
\text { dev. }\end{array}$ & 1 & 2 & 3 & 4 & 5 \\
\hline 1. Person-organization Fit & 5 & 4.08 & 0.81 & .91 & & & \\
\hline $\begin{array}{l}\text { 2. Organizational } \\
\text { identification }\end{array}$ & 10 & 3.91 & 1.06 & $.42^{* *}$ & .88 & & \\
\hline 3. Job performance & 7 & 3.85 & 1.18 & $.51^{* *}$ & $.44^{* *}$ & $\mathbf{. 8 6}$ & \\
\hline $\begin{array}{l}\text { 4. Production deviance } \\
\text { behavior }\end{array}$ & 4 & 2.87 & 1.82 & $-.41^{* *}$ & $-.33^{* *}$ & $-.18^{*}$ & $\mathbf{. 8 2}$ & \\
\hline \begin{tabular}{l} 
5. Intention to remain \\
\hline
\end{tabular} & 5 & 4.26 & 0.79 & $.67^{* *}$ & $.59^{* *}$ & $.24^{*}$ & $-.47^{* *}$ & $\mathbf{. 9 4}$ \\
\hline
\end{tabular}

Notes: $\mathrm{N}=582, * 0.05$ (Pearson Correlation-two tailed), ${ }^{*} 0.01$ (Pearson Correlation-two tailed), Values in bold are reliability (alpha coefficient).

other hand, while O-Id has a positive linear and significant relationship with J-Perf $(\mathrm{r}=.44$; $\mathrm{p}<.01)$, and IntR $(\mathrm{r}=.59 ; \mathrm{p}<.01)$, it has a significant, yet negative relationship with PDB $(\mathrm{r}=-.33 ; \mathrm{p}<.01)$. It was concluded that employees who are identified with the organization have elevated intentions to remain; hence, their J-Perf is positively affected.

In SEM, the condition of accepting measurement model analysed on data set as a whole within the general structure depends on the fact that goodness-of-fit statistics are on expected level. In evaluating model fit there are various fit indices and certain statistical functions possessed by such indices (Bentler 1990; Jöreskog, Sörbom 2004). The indices used in current research are chi-square statistics $\left(\chi^{2}\right)$, RMSEA, GFI, CFI and NFI. In fit indices measures, RMSEA $\leq 0.08$ and $\chi^{2} \leq 2$ of ideal values indicates a perfect fit. Likewise, if GFI, CFI and NFI values are between $0-1$ and the approach of this value to 1 also indicate a better congruence of the model (Browne, Cudeck 1993; Jöreskog, Sörbom 2004). In current research, the values pertaining to fit indices have been on acceptable levels. At the end of analysis chi-square measurement has been found 557.26 and degree of freedom as (df) $294\left(x^{2} / \mathrm{df}=1.89 ; \mathrm{p}<.001\right)$, obtained results have been $\mathrm{RMSEA}=.062$, GFI $=.90, \mathrm{CFI}=.86$ and NFI $=.91$. The smallness of CFI from 0.90 does not point that the model is misfit. Hart (1994) argues that in mixed models the fit measure higher than 0.80 values is sufficient.

The findings of P-O fit has a positive and significant effect on employees' O-Id $(\mathrm{t}=5.62$; $\mathrm{p}<.001$ ). The positive effect on mutual communication and interaction, which relies on the compatibility of individuals with their vocation, environmental components and directors, can be positively influential on work outcomes also. Therefore, it is reasonable to argue that $\mathrm{P}-\mathrm{O}$ fit is a viable element in terms of organizational behavior issues. $\mathrm{P}-\mathrm{O}$ fit is equally effective on J-Perf too, in addition to O-Id. This fact is indicated via the positive and significant relationship between these two factors as demonstrated by the analysis results.

The increase in the P-O fit positively affects his/her J-Perf $(t=6.44 ; p<.001)$. Nonetheless, it is witnessed that $\mathrm{P}-\mathrm{O}$ fit has a significant yet negative directed effect on employees' potential behaviors towards production deviance $(t=-4.31 ; \mathrm{p}<.001)$. Yet the 
Table 2. The measurement values of factor groups

\begin{tabular}{|c|c|c|c|c|}
\hline Scale items & M & SD & t-value & $\begin{array}{l}\text { Standardized } \\
\text { factor } \\
\text { loadings }\end{array}$ \\
\hline \multicolumn{5}{|l|}{ Person-organization fit: $\alpha=0.91 ; A V E=0.68 ; C C R=.76$} \\
\hline $\begin{array}{l}\text { There is congruence between my own values and } \\
\text { the values of the organization I work for }\end{array}$ & 4.24 & .77 & $13.57 * * *$ & .95 \\
\hline $\begin{array}{l}\text { In this organization, there is congruence between } \\
\text { my own values and the values of the other } \\
\text { employees }\end{array}$ & 4.18 & .78 & $12.68 * * *$ & .93 \\
\hline $\begin{array}{l}\text { In this organization there is congruence between } \\
\text { my own values and the values of the directors }\end{array}$ & 4.08 & .81 & $11.14 * * *$ & .88 \\
\hline $\begin{array}{l}\text { In this e organization there is congruence between } \\
\text { my own values and the characteristics of the work } \\
\text { I perform }\end{array}$ & 3.98 & .83 & $10.52 * * *$ & .85 \\
\hline $\begin{array}{l}\text { In this organization there is congruence } \\
\text { between my personal expectations and provided } \\
\text { opportunities }\end{array}$ & 3.92 & .86 & $9.33 * * *$ & .81 \\
\hline \multicolumn{5}{|c|}{ Organizational identification: $\alpha=0.88 ; A V E=0.63 ; C C R=.74$} \\
\hline In this organization, I can find my own personality & 4.17 & .96 & $13.35 * * *$ & .94 \\
\hline It gives great pleasure to work in this organization & 4.11 & .98 & $13.28 * * *$ & .94 \\
\hline $\begin{array}{l}\text { I work in this organization, because of external } \\
\text { necessities }(R)\end{array}$ & 4.03 & 1.01 & $12.02 * * *$ & .90 \\
\hline $\begin{array}{l}\text { There are times I avoid mentioning that I work for } \\
\text { this organization }(\mathrm{R})\end{array}$ & 4.01 & 1.03 & $11.27 * * *$ & .89 \\
\hline This organization means everything to me & 3.94 & 1.04 & $10.18 * * *$ & .84 \\
\hline $\begin{array}{l}\text { I take the criticisms against my organization } \\
\text { personally }\end{array}$ & 3.87 & 1.06 & $9.42 * * *$ & .81 \\
\hline $\begin{array}{l}\text { I value the thoughts of other people regarding my } \\
\text { organization }\end{array}$ & 3.81 & 1.10 & $9.08 * * *$ & .79 \\
\hline $\begin{array}{l}\text { While mentioning my organization I generally } \\
\text { prefer to say "we" rather than "they" }\end{array}$ & 3.75 & 1.12 & $8.83 * * *$ & .77 \\
\hline I cherish my organization's success as if my own & 3.72 & 1.14 & $8.14 * * *$ & .74 \\
\hline $\begin{array}{l}\text { I take the compliments towards my organization } \\
\text { personally }\end{array}$ & 3.69 & 1.16 & $7.37 * * *$ & .72 \\
\hline \multicolumn{5}{|l|}{ Job performance: $\alpha=0.86 ; A V E=0.57 ; C C R=.71$} \\
\hline $\begin{array}{l}\text { I am aware of the responsibilities listed under my } \\
\text { job definition }\end{array}$ & 4.03 & 1.02 & $11.56^{* * *}$ & .88 \\
\hline I finish an assigned task timely & 3.98 & 1.05 & $11.24 * * *$ & .87 \\
\hline I finish an assigned task thoroughly & 3.92 & 1.13 & $10.55^{* * *}$ & .84 \\
\hline
\end{tabular}


(End of Table 2)

\begin{tabular}{|c|c|c|c|c|}
\hline I assist my colleagues in my free time & 3.86 & 1.19 & $9.74 * * *$ & .80 \\
\hline $\begin{array}{l}\text { Neglecting my task adversely affects other } \\
\text { employees }\end{array}$ & 3.83 & 1.25 & $9.02 * * *$ & .78 \\
\hline I ask for help in tasks that I cannot handle alone & 3.71 & 1.29 & $8.61 * * *$ & .76 \\
\hline $\begin{array}{l}\text { I do my best to perform my job in the best } \\
\text { possible way }\end{array}$ & 3.62 & 1.33 & $8.39 * * *$ & .75 \\
\hline \multicolumn{5}{|c|}{ Production deviance behavior: $\alpha=0.82 ; A V E=0.51 ; C C R=.69$} \\
\hline $\begin{array}{l}\text { It is normal for me to leave work before I finish a } \\
\text { task (R) }\end{array}$ & 3.11 & 1.68 & $10.34 * * *$ & .83 \\
\hline $\begin{array}{l}\text { I am free to take breaks for lunch and rest as much } \\
\text { as I want (R) }\end{array}$ & 2.81 & 1.77 & $9.86^{* * *}$ & .81 \\
\hline $\begin{array}{l}\text { I do not stress myself to finish an assigned task } \\
\text { (R) }\end{array}$ & 2.79 & 1.90 & $9.68 * * *$ & .80 \\
\hline $\begin{array}{l}\text { I am not very careful with the tools, equipment } \\
\text { and materials I use at work (R) }\end{array}$ & 2.77 & 1.93 & $7.76^{* * *}$ & .74 \\
\hline \multicolumn{5}{|l|}{ Intention to remain: $\alpha=0.94 ; A V E=0.71 ; C C R=.79$} \\
\hline I am happy to be a member of this organization & 4.35 & .69 & $15.54 * * *$ & .97 \\
\hline I plan to work here in the future as well & 4.29 & .73 & $12.46^{* * *}$ & .92 \\
\hline $\begin{array}{l}\text { The opportunities provided in this organization are } \\
\text { satisfactory enough }\end{array}$ & 4.28 & .80 & $11.25 * * *$ & .90 \\
\hline $\begin{array}{l}\text { There is no negative situation that forces me to } \\
\text { leave this organization }\end{array}$ & 4.23 & .85 & $10.44 * * *$ & .86 \\
\hline In this organization, everyone likes/respects me & 4.15 & .88 & $9.65^{* * *}$ & .83 \\
\hline
\end{tabular}

Notes: Based on a scale ranging from 1(strongly disagree) to 5 (strongly agree), (R) Reversescored. $* * * \mathrm{p}<.001, \mathrm{AVE}=$ average variance extracted, $\mathrm{CCR}=$ composite construct reliability.

negative direction hereby does not mean a negation all together. To put simply, P-O fit has a preventive or diminishing effect in the emergence of PDBs. Such positive contribution of inter-factor relations can be at the same time be determinants of employees' intentions to remain. According to the analysis results, this approach is supported by the positive and significant relationship between $\mathrm{P}-\mathrm{O}$ fit and the employees' IntR and in general has a positive effect on the will of the employee to stay within the same organization, and the same assigned tasks $(\mathrm{t}=9.16 ; \mathrm{p}<.001)$. Accordingly, $\mathrm{H}_{1 \mathrm{a}}, \mathrm{H}_{1 \mathrm{~b}}$, $\mathrm{H}_{1 \mathrm{c}}$ and $\mathrm{H}_{1 \mathrm{~d}}$ hypotheses were supported.

Some salient findings were reached in measuring second-group hypotheses as well. Positively directed and significant relationship of the findings indicate that $\mathrm{O}-\mathrm{Id}$ has substantial effect on J-Perf is also parallel to conceptual data $(\mathrm{t}=6.22 ; \mathrm{p}<.001)$. It is seen that a person's identification with the organization is not only related to his/ her J-Perf, but is also effective in preventing the occurrence of PDBs. The negative and significant relationship between these two factors is an indicator of this finding 
Table 3. The result of hypotheses

\begin{tabular}{|c|c|c|c|c|}
\hline & Factors & $\begin{array}{l}\text { Standardized } \\
\text { coefficient }\end{array}$ & t-value & Result \\
\hline $\begin{array}{l}\text { Person-organization } \\
\text { fit }\end{array}$ & $\begin{array}{l}\text { Organizational identification } \\
\left(\mathrm{H}_{1 \mathrm{a}}\right) \\
\text { Job performance }\left(\mathrm{H}_{1 \mathrm{~b}}\right) \\
\text { Production deviance behavior } \\
\left(\mathrm{H}_{1 \mathrm{c}}\right) \\
\text { Intention to remain }\left(\mathrm{H}_{1 \mathrm{~d}}\right)\end{array}$ & $\begin{array}{l}.37 \\
.48 \\
-.34 \\
.61\end{array}$ & $\begin{array}{c}5.62 \\
6.44 \\
-4.31 \\
9.16 \\
\end{array}$ & $\begin{array}{l}\text { Supported } * * * \\
\text { Supported } * * * \\
\text { Supported*** } \\
\text { Supported } * * *\end{array}$ \\
\hline $\begin{array}{l}\text { Organizational } \\
\text { identification }\end{array}$ & $\begin{array}{l}\text { Job performance }\left(\mathrm{H}_{2 \mathrm{a}}\right) \\
\text { Production deviance behavior } \\
\left(\mathrm{H}_{2 \mathrm{~b}}\right) \\
\text { Intention to remain }\left(\mathrm{H}_{2 \mathrm{c}}\right)\end{array}$ & $\begin{array}{c}.48 \\
-.31 \\
.64 \\
\end{array}$ & $\begin{array}{c}6.22 \\
-3.25 \\
9.78\end{array}$ & $\begin{array}{l}\text { Supported } \\
\\
\text { Supported } \\
\text { S*** } \\
\text { Supported } \\
\text { *** }\end{array}$ \\
\hline & $\begin{array}{l}\chi^{2} \\
\mathrm{df} \\
x^{2} / \mathrm{df} \\
\text { GFI } \\
\text { AGFI } \\
\text { NFI } \\
\text { NNFI } \\
\text { CFI } \\
\text { IFI } \\
\text { RMSEA } \\
\text { SRMR }\end{array}$ & $\begin{array}{l}557.26 \\
294 \\
1.89 \\
.90 \\
.90 \\
.91 \\
.92 \\
.86 \\
.94 \\
.062 \\
.071\end{array}$ & & \\
\hline
\end{tabular}

Notes: $* * * \mathrm{p}<.001$. GFI = goodness-of-fit index; AGFI = adjusted goodness-of-fit index; NFI = normed fit index; NNFI = non-normed fit index; CFI = comparative fit index; IFI = incremental fit index; RMSEA = root mean square error of approximation; SRMR = standardized root mean residual.

$(\mathrm{t}=-3.25 ; \mathrm{p}<.001)$. This also affects in the end whether employees choose or not choose to remain in the same organization. An employee self-identified with the organization has congruence with colleagues, management and other components hence his/ her IntR is strengthened and a positive effect is created $(t=9.78 ; p<.001)$. According to the findings $\mathrm{H}_{2 \mathrm{a}}, \mathrm{H}_{2 \mathrm{~b}}$, and $\mathrm{H}_{2 \mathrm{c}}$ hypotheses were supported.

\section{Discussions and conclusions}

It has thus been concluded that in reaching organizational goals as much as personal goals employees' fit with their job, vocation, colleagues, management and other intraorganization elements have a noteworthy effect. In P-O fit the basic approach underscores that employee qualities and abilities should match organizational values. It means that in ensuring organizational success, a fair and ethical procedure, distribution and a management free from stress and conflict that can fulfil employees' job satisfaction, in addition to $\mathrm{P}-\mathrm{O}$ fit matter substantially. The clear manifestation that $\mathrm{P}-\mathrm{O}$ fit is related to both $\mathrm{O}-\mathrm{Id}$ and the remaining internal factors proves that remarkable findings have been obtained in this research. 
It was detected that the findings obtained thereby correspond greatly to the data contained in the relevant literature. However, due to the restricted number of studies specifically analysing the research of hospitality, the current research could be misleading at this stage in arriving at a conclusion through comparison. Still a comparison with general research indicates that there are some similarities in addition to differences. Previous studies (e.g. Ambrose et al. 2008; Andrews et al. 2011; Jung, Yoon 2013; Song, Chathoth 2011) highlighted that P-O fit has major effects on work outcomes, yet its connection with some organizational deviance behaviors has been neglected. Distinguished from other studies, the present research has illustrated that, as in work outcomes, PDBs are also affected by P-O fit. It is a fact that PDBs, which are constituents of organizational deviance behaviors, matter greatly for organizational goals. Alleviating such behaviors by means of $\mathrm{P}-\mathrm{O}$ fit can provide remarkable financial and social contributions to enterprises. J-Perf can be assessed in a variety of ways. In this research, the individuals were asked to self-evaluate their J-Perf via question statements associated with certain measures such as time, quality and quantity within the framework of the performed job, mission and responsibility. The findings demonstrated that P-O fit has a salient effect on the increase in J-Perf. The factors influential on the intentions of employees to remain can differ on both a personal and organizational level (Lee, Way 2010; Van Dick et al. 2004). Based on these different elements stated in the literature, there are some cases related to a $\mathrm{P}-\mathrm{O}$ misfit. As indicated in the findings section of the analysis results, P-O fit is positively influential on employees' intentions to remain. It is considered normal that an employee, who has a high quality of work life, job satisfaction, and obtains financial and social support, will have no intention to leave his/her current job.

In this research, a finding parallel to the relevant literature (Kim et al. 2013; Nikolaou 2003; Song, Chathoth 2011; Vogel, Feldman 2009) revealing that P-O fit has a positive effect on organizational commitment and identification with the employees was obtained. It is not reasonable to argue that O-Id stems from a relatively few number of agents. Once identification is defined as a further dimension of commitment level, it can be understood that identification is shaped through various agents in many different ways. Thus, the multidimensionality provided by $\mathrm{P}-\mathrm{O}$ fit can also be perceived by O-Id also. As obviously evident through the results of the analysis obtained in this research, $\mathrm{P}-\mathrm{O}$ fit has a positive effect on the identification of the employees with the organization. This finding points to the fact that to reach organizational goals, success is easier to achieve by motivating the employees.

In the literature, there are some results in different ways and levels explaining the relationship of O-Id with work outcomes. As explained in the theoretical framework and conceptual section, as well in previous research, O-Id has been associated with different dimensions of work outcomes. However, there are a restricted number of studies dealing with hospitality organizations, and its relationship with employee deviance behavior. Even so, it has been concluded that O-Id has a substantial effect on work outcomes. Particularly in J-Perf, it is acknowledged that the individuals who fail to identify with the organization cannot work effectively and productively enough. For this reason, in 
securing J-Perf it should be highlighted that the interaction and identification between the organization and individual matter considerably.

Research findings show that O-Id is among the factors influential on employees' J-Perf. It is not probable that an employee identified with the organization will be engaged in deviant behaviors. From this perspective, O-Id assumes a major role in creating a suitable setting to prevent the emergence of this type of behavior. The results of the analysis put forth, that O-Id is effective in alleviating PDBs. It is assumed that in organizations with elevated work life quality, O-Id is also an influential factor. In that case, the intention of the employee to remain does not lessen. In other words, it is clear that O-Id has a huge bearing on the employees' IntR. As a result, the findings obtained in this research are parallel to the information available in the related literature, which also indicates that the created conceptual model was structured correctly and validly.

\section{Limitations and suggestions for future research}

This study has some limitations. One of them is related to survey respondents and interviewees were all based in a tourism region of Turkey. It is restricted to hospitality organizations operating in the Mugla region of Turkey; hence, the obtained findings cannot be generalized to the businesses operating in other regions or in different sectors. Analysing the prospective research from different dimensions to include hospitality organizations operating in different regions bears importance in terms of conducting comparisons with similar studies. The second, all respondents were full-time work status and had been working for a minimum one year in 5-star hotels. A third limitation is that the relation between demographic factors and main factors in research (P-O fit, O-Id, J-Perf, PDB, and the IntR). The demographic characteristics of the participants are not directly related to the aim of this research; therefore, it was excluded from the context of the research.

Future research in hospitality organizations could examine whether demographic characteristics of the participants are associated with P-O fit and work outcomes. Future research could also investigate the relationships among the P-O fit, justice perceptions and organizational commitment. Further research could be conducted to compare and gain a general outcome of study in travel, airline, entertainment, food and beverage organizations and others in tourism sector and also in different tourism regions and countries.

\section{References}

Ambrose, M. L.; Arnaud, A.; Schminke, M. 2008. Individual moral development and ethical climate: the influence of person-organization fit on job attitudes, Journal of Business Ethics 77: 323-333. http://dx.doi.org/10.1007/s10551-007-9352-1

Andrews, M. C.; Baker, T.; Hunt, T. G. 2011. Values and person-organization fit: does moral intensity strengthen outcomes?, Leadership \& Organization Development Journal 32(1): 5-19. http://dx.doi.org/10.1108/01437731111099256

Aquino, K.; Galperin, B. L.; Bennett, R. J. 2004. Social status and aggressiveness as moderators of the relationship between interactional justice and workplace deviance, Journal of Applied Social Psychology 34(5): 1001-1029. 
Bennett, R. J.; Robinson, S. L. 2003. The past, present, and future of workplace deviance research, in J. S. Greenberg (Ed.). Organizational behavior: the state of the science. USA: Lawrence Erlbaum Associate, 247-282.

Bentler, P. M. 1990. Comparative fit indexes in structural models, Psychological Bulletin 107: 238-246. http://dx.doi.org/10.1037/0033-2909.107.2.238

Browne, M. W.; Cudeck, R. 1993. Alternate ways of assessing model fit, in K. A. Bollen, J. S. Long (Eds.). Testing structural equation models. Newbury Park, CA: Sage Publications, 136-162.

Cable, D. M.; DeRue, D. S. 2002. The convergent and discriminant validity of subjective fit perceptions, Journal of Applied Psychology 87(5): 875-884.

http://dx.doi.org/10.1037/0021-9010.87.5.875

Carless, S. A. 2005. Person-job fit versus person-organization fit as predictors of organizational attraction and job acceptance intentions: a longitudinal study, Journal of Occupational and Organizational Psychology 78: 411-429. http://dx.doi.org/10.1348/096317905X25995

Carmeli, A.; Gilat, G.; Waldman, D. A. 2007. The role of perceived organizational performance in organizational identification, adjustment and job performance, Journal of Management Studies 44(6): 972-992.

Chatman, J. 1991. Matching people and organizations: selection and socialization in public accounting firms, Administrative Science Quarterly 36: 459-484.

Christensen, R. K; Wright, B. E. 2011. The effects of public service motivation on job choice decisions: disentangling the contributions of person-organization fit and person-job fit, Journal Public Administration Research Theory 21(4): 723-743. http://dx.doi.org/10.1093/jopart/muq085

Da Silva, N.; Hutcheson, J.; Wahl, G. D. 2010. Organizational strategy and employee outcomes: a person-organization fit perspective, The Journal of Psychology 144(2): 145-161.

De Clercq, S.; Fontaine, J. R. J.; Anseel, F. 2008. In search of a comprehensive value model for assessing supplementary person-organization fit, The Journal of Psychology 142(3): 277-302.

Demir, M. 2010. The effects of emotional intelligence on human resources selection: a research on managers of accommodation enterprises, International Journal of Human Sciences 7(1): 1066-1081.

Demir, M. 2011. Effects of organizational justice, trust and commitment on employees' deviant behavior, Anatolia: an International Journal of Tourism and Hospitality Research 22(2): 204-221. http://dx.doi.org/10.1080/13032917.2011.597934

Dutton, J. E.; Dukerich, J. M.; Harquail, C. V. 1994. Organizational images and member identification, Administrative Science Quarterly 39(2): 239-263.

Edward, M. R. 2005. Organizational identification: a conceptual and operational review, International Journal of Management Reviews 7(4): 207-230.

Edwards, J. R. 1991. Person-job fit: a conceptual integration, literature review, and methodological critique, in C. L. Cooper, I. T. Robertson (Eds.). International review of industrial and organizational psychology. New York: Wiley, 283-357.

Fox, S.; Spector, P. E.; Miles, D. 2001. Counterproductive work behavior (CWB) in response to job stressors and organizational justice: some mediator and moderator tests for autonomy and emotions, Journal of Vocational Behavior 59(3): 291-309.

Hart, P. M. 1994. Teacher quality of work life: integrating work experiences, psychological distress and morale, Journal of Occupational Psychology 67(2): 109-32.

Hollinger, R. C.; Clark, J. P. 1982. Formal and informal social controls of employee deviance, The Sociological Quarterly 23(3): 333-343. 
Janssen, O.; Van Yperen, N. W. 2004. Employees' goal orientations, the quality of leader-member exchange, and the outcomes of job performance and job satisfaction, Academy of Management Journal 47(3): 368-384.

Johari, J.; Yahya, K. K. 2009. Linking organizational structure, job characteristics, and job performance constructs: a proposed framework, International Journal of Business and Management 4(3): $145-152$.

Jöreskog, K. G.; Sörbom, D. 2004. LISREL 8.7 for Windows [Computer software]. Lincolnwood, IL: Scientific Software International Inc.

Jung, H. S.; Yoon, H. H. 2013. The effects of organizational service orientation on personorganization fit and turnover intent, The Service Industries Journal 33(1): 7-29.

http://dx.doi.org/10.1080/02642069.2011.596932

Katzell, R. A.; Thompson, D. E.; Guzzo, R. A. 1992. How job satisfaction and job performance are and are not linked, in C. J. Cranny, P. C. Smith, E. F. Stone (Eds.). Job satisfaction. New York: Lexington Books, 195-218.

Kim, T. Y.; Aryee, S.; Loi, R.; Kim, S. P. 2013. Person-organization fit and employee outcomes: test of a social exchange model, The International Journal of Human Resource Management 24(19): 3719-3737. http://dx.doi.org/10.1080/09585192.2013.781522

Kristof-Brown, A. L.; Zimmerman, R. D.; Johnson, E. C. 2005. Consequences of individuals' fit at work: a meta-analysis of person-job, person-organization, person-group, and person-supervisor fit, Personnel Psychology 58(2): 281-342. http://dx.doi.org/10.1111/j.1744-6570.2005.00672.x

Lawrence, T. B.; Robinson, S. L. 2007. Ain't misbehavin: workplace deviance as organizational resistance, Journal of Management 33(3): 378-394. http://dx.doi.org/10.1177/0149206307300816 Lee, C.; Way, K. 2010. Individual employment characteristics of hotel employees that play a role in employee satisfaction and work retention, International Journal of Hospitality Management 29(3): 344-353.

Liu, B.; Liu, J.; Hu, J. 2010. Person-organization fit, job satisfaction, and turnover intention: an empirical study in the Chinese public sector, Social Behavior and Personality 38(5): 615-626. http://dx.doi.org/10.2224/sbp.2010.38.5.615

Mael, F.; Ashforth, B. E. 1992. Alumni and their alma mater: a partial test of the reformulated model of organizational identification, Journal of Organizational Behavior 13(2): 103-123. http://dx.doi.org/10.1002/job.4030130202

Miller, V. D.; Allen, M.; Casey, M. K.; Johnson, J. R. 2000. Reconsidering the organizational identification questionnaire, Management Communication Quarterly 13(4): 626-658.

Morrow, P .C.; McElroy, J. C.; Laczniak, K. S.; Fenton, J. B. 1999. Using absenteeism and performance to predict employee turnover: early detection through company records, Journal of Vocational Behavior 55(3): 358-374. http://dx.doi.org/10.1006/jvbe.1999.1687

Mowday, R.; Porter, L.; Steers, R. 1982. Employee-organization linkages: the psychology of commitment, absenteeism and turnover. New York: Academic Press.

Nagy, M. S. 2002. Using a single-item approach to measure facet job satisfaction, Journal of Occupational and Organizational Psychology 75(1): 77-86.

Nair, N.; Bhatnagar, D. 2011. Understanding workplace deviant behavior in nonprofit organizations, Nonprofit Management and Leadership 21(3): 289-309. http://dx.doi.org/10.1002/nml.20026

Nikolaou, I. 2003. Fitting the person to the organisation: examining the personality-job performance relationship from a new perspective, Journal of Managerial Psychology 18(7): 639-648.

Olkkonen, M. E.; Lipponen, J. 2006. Relationships between organizational justice, identification with organization and work unit, and group-related outcomes, Organizational Behavior and Human Decision Processes 100(2): 202-215. http://dx.doi.org/10.1016/j.obhdp.2005.08.007 
O'Reilly, C. A.; Chatman, J.; Caldwell, D. F. 1991. People and organizational culture: a profile comparison approach to assessing person-organization fit, Academy of Management Journal 34(3): 487-516. http://dx.doi.org/10.2307/256404

Robbins, S. P. 1998. Organizational behavior. $8^{\text {th }}$ ed. Upper Saddle River, NJ: Prentice Hall.

Robinson, S. L.; Bennett, R. J. 1995. A typology of deviant workplace behaviors: a multidimensional scaling study, Academy of Management Journal 38: 555-572.

Ryan, A. M.; Schmit, M. J. 1996. An assessment of organizational climate and P-E fit: a tool for organizational change, The International Journal of Organizational Analysis 4(1): 75-95. http://dx.doi.org/10.1108/eb028842

Saks, A. M.; Ashforth, B. E. 2002. Is job search related to employment quality? It all depends on the fit, Journal of Applied Psychology 87(4): 646-654.

Sekuguchi, T. 2004. Person-organization fit and person job fit in employee selection: a review of literature, Osaka Keidei Ronshu 54(6): 179-196.

Shamir, B.; Kark, R. 2004. A single-item graphic scale for the measurement of organizational identification, Journal of Occupational and Organizational Psychology 77(1): 115-123.

Sluss, D. M.; Klimchak, M.; Holmes, J. J. 2008. Perceived organizational support as a mediator between relational exchange and organizational identification, Journal of Vocational Behavior 73(3): 457-464. http://dx.doi.org/10.1016/j.jvb.2008.09.001

Song, Z.; Chathoth, P. K. 2011. Intern newcomers' global self-esteem, overall job satisfaction, and choice intention: person-organization fit as a mediator, International Journal of Hospitality Management 30(1): 119-128. http://dx.doi.org/10.1016/j.ijhm.2010.03.003

Van Dick, R.; Wagner, U.; Stellmacher, J.; Christ, O. 2004. The utility of a broader conceptualization of organizational identification: which aspects really matter?, Journal of Occupational and Organizational Psychology 77(2): 171-191.

Van Knippenberg, D.; Sleebos, E. 2006. Organizational identification versus organizational commitment: self-definition, social exchange, and job attitudes, Journal of Organizational Behavior 27(5): 571-584. http://dx.doi.org/10.1002/job.359

Vardi, Y.; Wiener, Y. 1996. Misbehavior in organizations: a motivational framework, Organization Science 7(2): 151-167. http://dx.doi.org/10.1287/orsc.7.2.151

Vogel, R. M.; Feldman, D. C. 2009. Integrating the levels of person-environment fit: the roles of vocational fit and group fit, Journal of Vocational Behavior 75(1): 68-81.

Wan-Huggins, V. N.; Riordan, C. M.; Griffeth, R. W. 1998. The development and longitudinal test of a model of organizational identification, Journal of Applied Social Psychology 28(8): 724-749.

Williams, L. J.; Anderson, S. E. 1991. Job satisfaction and organizational commitment as predictors of organizational citizenship and in-role behaviours, Journal of Management 17(3): 601-617.

Mahmut DEMIR, Dr, is Associate Professor of Tourism Management in the Department of Hospitality Management, Suleyman Demirel University, Isparta, Turkey. He has BBA, MBA and PhD in Tourism Management. His current research interests are: tourism management, human resources management, organizational behaviour, tourism education and research method for business. He has published books, book chapters and articles in national and international journals and presentations in conference books. He teaches Tourism and Business administration courses at graduate and undergraduate levels. He serves as a reviewer and on editorial boards of national and international journals of tourism.

Şirvan Şen DEMIR, Dr, is Head of Department of Hospitality Management and Assistant Professor of Tourism Management in the Department of Hospitality Management, Suleyman Demirel University, 
Isparta, Turkey. She has BBA, MBA and $\mathrm{PhD}$ in Tourism Management. Her current research interests are: tourism management, tourism marketing, consumer behavior, communication techniques and public relations, and customer relation management. She has published books and articles in national and international journals and presentations in conference books. She teaches Tourism course at undergraduate levels. She serves as a reviewer of national and international journals of tourism.

Kevin NIELD, Dr, is Head of Department of Service Sector Management in Sheffield Business School. Before taking up his present position at SHU Kevin has worked in a wide variety of positions within the catering and retail industries and in further education. He has co-researched three editions of the British Hospitality Association's annual British Hospitality: Trends and Statistics and is joint author of Contemporary Issues in Hospitality and Tourism in China and India. Kevin has a particular interest in education and is a honorary associate of the HE Academy network for Hospitality, Leisure, Tourism, Sport and Food and the Director of Education for EuroCHRIE. He has represented the sector on QAA working groups and panels. 